\title{
Political bargaining practices through federal budget execution
}

\author{
Luis Henrique Teixeira Graton 1 \\ Carlos Alberto Grespan Bonacim ${ }^{2}$ \\ Sérgio Naruhiko Sakurai ${ }^{2}$ \\ 1 Faculdade de Filosofia, Ciências e Letras de Ituverava, Ribeirão Preto / SP - Brazil \\ 2 Universidade de São Paulo / Faculdade de Economia, Administração e Contabilidade, Ribeirão Preto / SP - Brazil
}

The Brazilian budgetary process has historically been questioned based on the alleged use of political bargaining in the inclusion and implementation of amendments from deputies to the executive's budget, which affects the principles, criteria, and practices of allocative choices. Supported by the theory of coalition formation, this article examines a possible political bargaining relationship between the executive and legislative branches in the budgetary process at the federal level. The study analyzed the execution of amendments from deputies over five mandates (between 2000 and 2017) and the deputies' votes on projects proposed by the executive. Data regarding the execution of singular amendments were also analyzed, together with information concerning the deputies' political position toward the executive when proposing amendments. Econometric techniques were employed to correct selection bias, assessing the presence of political bargaining. The results corroborate the hypothesis that there is political bargaining in the relationship between the executive and legislative branches in Brazil. The deputy who had more of their amendments executed by the government was also the one that voted with the government in the bills sent from the executive to the legislative, even though they were not part of the governing coalition in the Congress. Therefore, the executive targeted deputies who were not part of the governing coalition to increase the number of votes in Congress.

Keywords: coalition presidentialism; budgeting process; singular amendments; political bargaining.

\section{Práticas de barganha política por meio da execução orçamentária federal}

O processo orçamentário brasileiro tem sido historicamente questionado pela suposta presença de barganha política na inclusão e na execução de emendas ao orçamento, fato que interfere nas premissas, nos critérios e nas práticas das escolhas alocativas. Este artigo, sustentado pela Teoria da Formação de Coalizões, investiga a existência de uma possível relação de barganha política entre os poderes Executivo e Legislativo no processo orçamentário na esfera federal. Tal pesquisa ocorre por meio da análise das execuções de emendas parlamentares singulares ao longo de cinco legislaturas (entre 2000 e 2017) e das decisões dos deputados na votação de projetos propostos pelo Executivo. Analisaram-se dados referentes à execução de emendas singulares, bem como aqueles concernentes à posição política do parlamentar com relação ao Executivo no instante da proposição das emendas. A metodologia envolveu técnicas econométricas que lidam com a correção do viés de seleção para avaliar a presença ou não da referida relação de barganha. Os resultados obtidos corroboram a hipótese de existência de barganha política entre os poderes Executivo e Legislativo, pois o parlamentar com maior aporte de execução de suas emendas singulares foi aquele que, além de ter exercido apoio ao Executivo através de votos favoráveis aos projetos enviados ao congresso nacional, era de fora da coligação de governo, alvo do Executivo na formação do quorum mínimo para a aprovação de seus projetos.

Palavras-chave: presidencialismo de coalizão; processo orçamentário; emendas singulares; barganha política.

\footnotetext{
DOI: http://dx.doi.org/10.1590/0034-761220190399x
Article received on November 2, 2019 and accepted A

Article received on November 2, 2019 and accepted August 19, 2020.

[Translated version] Note: All quotes in English translated by this article's translator.
} 


\section{Prácticas de regateo político mediante la ejecución presupuestaria federal}

El proceso presupuestario brasileño ha sido históricamente cuestionado por la supuesta presencia de regateo político en la inclusión y ejecución de enmiendas al presupuesto, hecho que interfiere con las premisas, criterios y prácticas de las decisiones distributivas. Este artículo, apoyado en la Teoría de la Formación de Coaliciones, investiga la existencia de una posible relación de regateo político entre los poderes Ejecutivo y Legislativo en el proceso presupuestario a nivel federal. Dicha investigación se da a través del análisis de las ejecuciones de enmiendas parlamentarias singulares en cinco legislaturas (entre 2000 y 2017) y de las decisiones de los diputados en la votación de proyectos propuestos por el Ejecutivo. Se analizaron datos referentes a la ejecución de enmiendas singulares, así como los referentes a la posición política del parlamentario frente al Ejecutivo al momento de la proposición de las enmiendas. La metodología involucró técnicas econométricas que tratan la corrección del sesgo de selección para evaluar la presencia o ausencia de la referida relación de regateo. Los resultados obtenidos corroboran la hipótesis de existencia de regateo político entre los poderes Ejecutivo y Legislativo, ya que el parlamentario con mayor aporte de ejecución de sus enmiendas singulares fue quien, además de haber apoyado al Ejecutivo a través de votos a favor de los proyectos remitidos al Congreso Nacional, era ajeno a la coalición de gobierno, objetivo del Ejecutivo en la formación del quórum mínimo para la aprobación de sus proyectos.

Palabras clave: presidencialismo de coalición; proceso presupuestario; enmiendas singulares; regateo político.

\section{INTRODUCTION}

Accusations of corruption, the impeachment of the President of the Republic and the opening of investigations, such as Congressional Inquiry Commissions (CPI), among other recent scandals have drawn the attention of Brazilian society and academia to our, if not fragile, questionable political stability. The evident crisis in governability occurs in all spheres of power and at times generates conflict between the three branches and the judicialization of decisions and administrative acts: the 2016 impeachment process which ended the mandate of President Dilma Rousseff, the accusations against President Michel Temer in the Supreme Court (STF) which led to exhaustive sessions of the House of Representatives and ended with his acquittal in 2017, and the recent public crises and clashes between President Jair Bolsonaro and these institutions.

The crisis and this turbulent moment in Brazilian politics have presented elements which raise important discussions about the mechanisms used to maintain governability, as well as the harmony (or disharmony) among the three branches. Coalition Formation Theory addresses the governmental mechanisms for maintaining a governing coalition through political parties (Figueiredo \& Limongi, 2006; Limongi \& Figueiredo, 1998; Santos, 2002). In this way, the executive branch achieves the governability it needs to make its strategies and programs viable (because they depend on legislative approval of the budget), strengthening allied representatives who are closer ideologically, as well as resources through the execution of amendments for more distant congressmen (Pereira \& Orellana, 2009).

Thus, we have possible discretion attributed to the executive branch in the realization of non-mandatory expenses (Kanayama, 2009; Gontijo, 2010; Lima \&Viana, 2016). Added to the interests of the legislative branch in clientelist politics, through which it manages to execute amendments which benefit its main electoral bases (Kang, 2018; Pereira, 2000; Weingast, Shepsle, \& Johnsen, 1981), this weakness creates the possibility of political bargains between the branches. Political bargains can be understood as concessions of favors to individuals who desire advantages or privileges which satisfy 
their interests. Translating this to the language of the public sector, these interests can be summarized as maintaining the power of the political agent.

The phenomenon addressed in this article can be portrayed in the public budgeting process on the federal level in the following situation: the executive branch seeking to maintain or even increase the unity of its coalition (Pereira \& Mueller, 2002; Riker, 1962; Scartacini \& Crain, 2001) will look to execute congressional amendments in exchange for support for its bills when they are voted on in congress (Bertholini \& Pereira, 2017; Martins, 2016; Ravanelli, Costa, \& Bonacim, 2012). Even though these studies have addressed parts of this phenomenon, the purpose of this article is not to characterize the behavior of the executive branch, something which has already been addressed by the existing literature, but rather that of the key congressmen who ensure the execution of the executive branch's bills and the resulting perpetuation of its coalition, using political bargains.

Therefore, this sustains the hypothesis that in the search for governability (united due to the need to approve bills, to form and govern a coalition and increase its governability), the executive branch uses its discretion to execute congressional amendments in order to implement its bills and reforms.

Thus, this study has the objective of finding evidence of political bargains on the federal level between the executive and legislative branches through the execution process of congressional amendments. To accomplish this, this study analyzes budgetary execution data as well as data relative to congressmen from five legislatures formed by various governments and coalitions. We have also sought to identify how much more political support alters the monetary amounts spent in the execution of the amendments of congressmen who opt for this type of relationship.

The results obtained reinforce the idea that the discretion of the executive branch joins forces with the clientelist interests of its coalition for the approval of bills and the execution of amendments. This is because the congressmen with the greatest monetary investments in their amendments over the period examined were the ones which, in addition to the support given to the executive branch through favorable votes for the bills sent to congress, were outside the government's coalition. This fact reinforces the thesis that these congressmen are targeted by the executive branch to form a minimal quorum to approve its bills.

\section{WHAT IS BEHIND THE PHENOMENON: COALITION FORMATION THEORY}

As already mentioned, the discretion of the executive branch in choosing to execute congressional demands or not, added to the absence of corporate governance mechanisms in the budgeting process, permits the occurrence of political bargains between the executive and legislative branches in the execution of budgetary amendments. In this situation, both seek to satisfy their interests and preserve their political status to the potential detriment of the public interest (Lima \& Viana, 2016; Martins, 2016).

Within this context, an important factor for the executive branch emerges which is fundamental to its governability when dealing with a fragmented or multiparty legislative branch, namely the formation and management of its base of support in the legislative branch. This will facilitate the approval of its 
bills, which certainly will be presented to the legislature. This base is termed the coalition (Figueiredo \& Limongi, 2006; Santos, 2002).

The need of governments to construct coalitions and the resulting search for the approval of its bills by congress, makes it possible to analyze the phenomenon of political bargains which is addressed here, from which the Coalition Formation Theory emerges - which we will henceforth refer to as CFT (Limongi \& Figueiredo, 1998).

Originally grounded in studies of parliamentary governments, this theory has been also applied to not just presidential but multiparty governments such as Brazil (Chaisty, Cheeseman, \& Power, 2014; Cheibub, Przeworski, \& Saiegh, 2004; Bertholini \& Pereira, 2017).

Seeking not only to form at least a winning coalition, but coalitions large enough to ensure legislative victories (Riker, 1962), it may be observed that the need of the executive branch to maintain unity and discipline may make the process of governing excessively expensive (Pereira \& Mueller, 2002). This aggregates more costs for the head of the government, which are reflected in the execution of the public budget, the object of this study.

As if the difficulty of the executive in managing its coalition were not enough (given the multiparty nature of Brazilian politics), a government needs to use everything within its reach to have freedom to execute its policies. Another important aspect of the analyzed phenomenon is the already mentioned interest of members of the legislature in clientelist politics. In particular, being mainly preoccupied in maintaining their future electability and political careers, these agents prioritize the proposal and execution of amendments which benefit their main electoral bases. In this manner, a point in common emerges between the executive and legislative branches: the fact that both desire to maintain power, independent of their intermediary motives.

Capellini (2018) proposes a theoretical model which explains the relationship between the executive and legislative branches in the distribution of public resources. This model takes into account the uncertainty in terms of the voting behavior of congressmen and supposes that negotiations between these powers occur on three levels: wholesale, retail and customized.

In wholesale, governmental strategies to form party alliances and distribute powerful positions prevail, especially in ministries. According to Capellini (2018), the congressmen who act on this level tend to be faithful to their parties and more disciplined in their voting, generating less uncertainty for the executive. Congressmen who act in retail not only present less faithful behavior to their parties (greater uncertainty about their voting), but are also more likely to switch parties. This makes predicting their voting behavior even more difficult.

In principle, it is conjectured that it is not possible to affirm that one or another type of negotiation is more advantageous in optimizing the obtaining of resources, however, theoretically, congressmen who negotiate in a retail manner depend on (or desire more) resources via the settling of congressional amendments, because being outside the distribution of positions, this is their currency of exchange. Finally, going beyond wholesale and retail negotiations, the third level involves the customized sale of votes which occurs occasionally involving the support of a given congressman which depends upon receiving a specific reward, possibly in the form of the settlement of amendments.

Thus, since there are levels of negotiation in the distribution of resources, there is also government interest in these votes. Understanding the relevance of each vote is fundamental for congressmen to 
position themselves adequately in the bargaining arena. Congressmen who act in retail can diminish their support for the government in certain votes when these represent a potential loss of their political capital. This risk for congressmen is identified, for example, in voting on accusations against the president, due to the great social commotion involved.

Therefore, except for the possibility of voting for ideological or programmatic affinity, congressmen who act in a retail manner tend to diminish their support for the government coalition in votes which represent risk to the president. However, this may change if they are coopted, which would lead them to the arena of customized political bargains.

In this manner, a retail negotiation should reflect a fall in the adherence to the coalition in situations where the president's force is diminished, while the propensity to be coopted should reflect an increase in support for the government coalition in these votes. Meanwhile, congressmen who act in a wholesale manner are affected by these votes according to the dynamics of party alliances.

Given the theoretical model presented above, we will test the following hypotheses in this study:

- $\mathrm{H}_{0}$ : Congressmen who support the executive branch in congressional votes do not receive greater benefits in the execution of their amendments compared to other congressmen.

- $\mathrm{H}_{1}$ : Congressmen who support the executive branch in congressional votes receive greater benefits in the execution of their amendments compared to other congressmen.

\section{PARTICULARITIES OF BRAZILIAN GOVERNMENT BUDGETS}

The construction process of Brazilian government budgets, as one of the main administrative instruments of the executive branch (on a program, execution and control level), is constantly changing in the search to improve its utility and mitigate errors which harm the fulfillment of society's needs. With the promulgation of the Constitution, various levels of government adopted mandatory innovative planning and budgeting instruments (Constituição da República Federativa do Brasil de 1988). This mandatory requirement listed in Article 3 of Complementary Law 101/2000 (Lei de Responsabilidade Fiscal) also requires the executive branch to elaborate a Multiyear Plan (MYP), in the first year of a given mandate, instituting in it in a regionalized manner, and including all the longterm guidelines, objectives and strategic priorities of the federal government. Later this plan is sent to congress, which has until December 15 to review, amend, approve and return it to the executive branch for approval.

From there the MYP lasts four years beginning with the second year of the president's mandate until the first year of the next mandate, inducing continuity in the planning process for the public sector. In addition to this plan, another instrument was implemented with the new Constitution in 1988, as the Law of Budgetary Guidelines (LBG), which the executive branch sends annually to the legislative branch, and which if approved, establishes fiscal targets and priorities for the government. Thus, together with the MYP, the LBG serves as a base to define its priorities in the elaboration of the Annual Budget Bill (ABB) for the current fiscal year.

After the budgets are elaborated with the ministry proposals, in which they define the parameters and targets for the Federal Budget Secretariat of the Ministry of Planning, Budgeting and Management, the $\mathrm{ABB}$ - with revenue estimates and expense determinations and their limits established by the 
programs for each of the ministries and public bodies - is sent to the congress. With its approval, it is sent to the president for approval (Giacomoni, 2008).

Once it is sent to congress, the budgetary materials are analyzed, discussed and reviewed by the Mixed Commission on Public Plans, Budgets and Oversight (MCB). ${ }^{1}$ This commission is formed by 40 congressmen, with 30 of them being representatives and 10 senators.

Within the context of the review by the $\mathrm{MCB}$, responsible for deliberating on budgetary instruments (MYP, LBG and ABB), as well as alterations with additional credits, the $\mathrm{ABB}$ receives amendments proposed by members of congress. These should be compatible with the MYP and the LBG in respect to timeframes and limits which rule the functionality of the commission. Analyzed by the legislature like any other law, the Proposed Budgetary Law is sent for the president's approval, and having attained this, it is published and executed during the following year.

The congressional amendments annexed to the Budgetary Plan can be proposed collectively or individually. They were limited to fifty per congressman ${ }^{2}$ and later reduced to twenty, ${ }^{3}$ and have recently been subjected to new limits by Constitutional Amendment (CA) 86 .

In order to make the public budget execution process less discretionary, Constitutional Amendment 86, passed in March 2015, altered Articles 165 and 166 of the Constitution, and linked 50\% of all amendments to health programs, establishing a limit of $1.2 \%$ of current net revenues ${ }^{4}$ for congressional amendment spending (Martins, 2016). However, according to Greggianin and Silva (2015), CA $86 / 2015$ also has its limitations, because it establishes that congressional amendments do not have to be executed if there is a technical or legal order which makes it impossible to execute all or part of the programs. In prioritizing the meeting of fiscal targets, this impediment provides a margin for the discretionary execution of budgetary expenses and places the executive in a favorable position in relation to political bargains with the legislature.

In addition, to ensure budgetary authorization, CA 100 was promulgated, which altered Articles 165 and 166 of the Constitution of 1988. This alteration ensured that in $\S 12$, the execution of "amendments initiated by state or federal congressmen were limited to up to $1 \%$ (one percent) of net revenues of the previous year." Before the referred to CA, the possibility of a budgetary amendment being imposed on the executive depended on individual amendments. However, this understanding was altered after this promulgation.

In this manner, despite all the negotiations and procedures to approve and sanction the amendments, before the above mentioned CAs there were no guarantees of their execution, given that it was up to the executive to execute or not execute a given amendment based on the financial resources available in the national treasury. Thus, the bargaining has been modified, although the executive still has mechanisms, such as preferences in the order of payment.

According to Kanayama (2009), the approval of the budgetary law just grants the authorization to the executive to effect a given expense, without enforcing its action. This power can also make

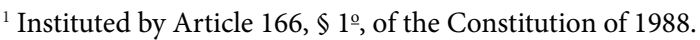

${ }^{2}$ Congressional Resolution no $1 / 1993$.

${ }^{3}$ Congressional Resolution $n^{-2}$ 2/1995, which also established a ceiling of R\$ 1.5 million in the total value of amendments per congressman.

${ }^{4}$ Due to taxes, industrial contributions, and farming and ranching services.
} 
amendments contingent on the availability of financial resources, as envisioned by the Law of Fiscal Responsibility (LFR). Thus, it seems reasonable to assume that the executive branch can take advantage of factors which provide it with more discretion in budgetary execution and greater bargaining power with the legislature, helping it maintain the unity of its coalition.

The theoretical model presented in the second section of this study proposes an analysis of the behavior of congressmen in relation to individual amendments proposed in the budget. The imposed budget has not eliminated the discretion of the executive: it has just limited its margin for action in the commitment stage. In this way, respecting the contingency norms during the settlement phase, the government can direct the resources of certain congressmen based on their support in votes which involve the interests of the executive branch, as can be seen in Figure 1.

FIGURE 1 INDIVIDUAL CONGRESSIONAL AMENDMENTS (ICA) IN THE IMPOSED BUDGET

Executive
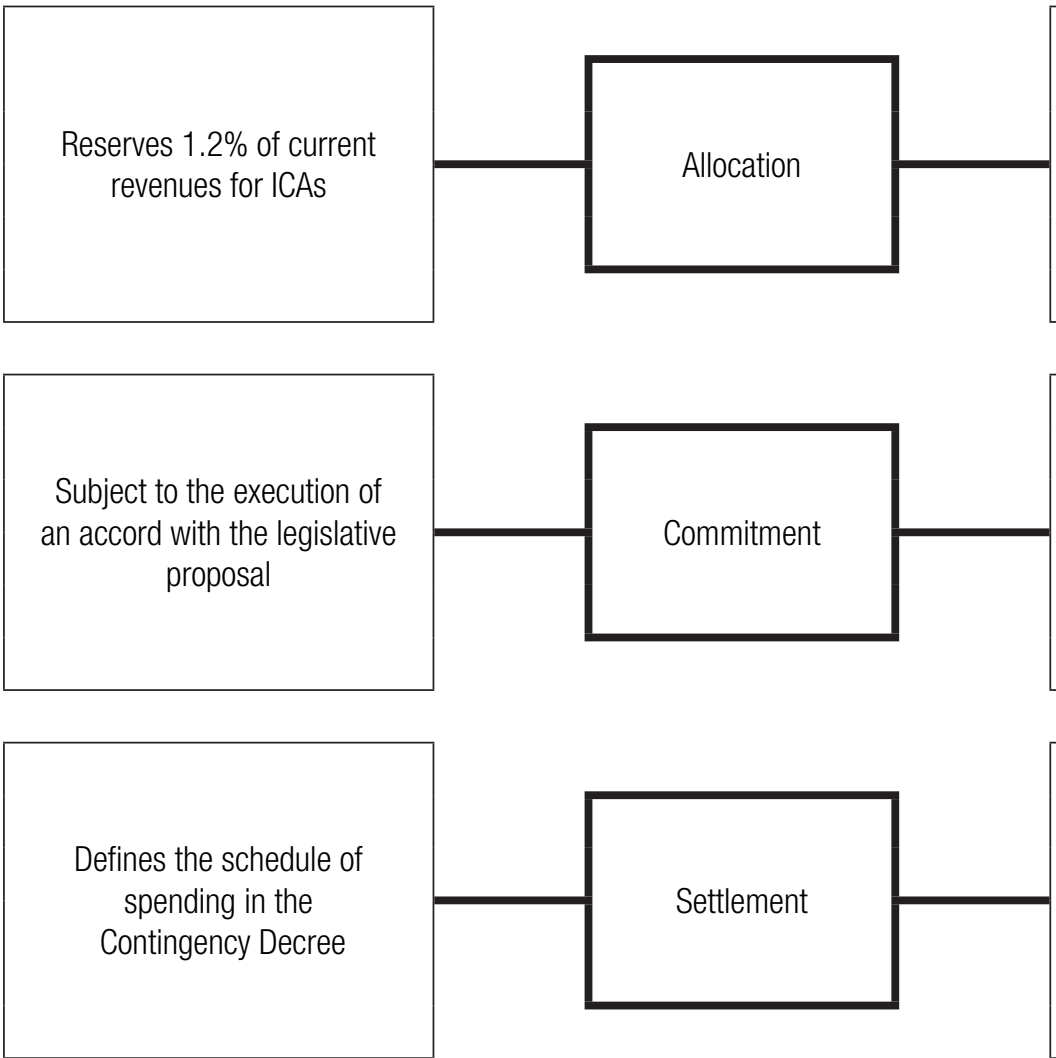

Legislature

Expense Stage in the Imposed Budget
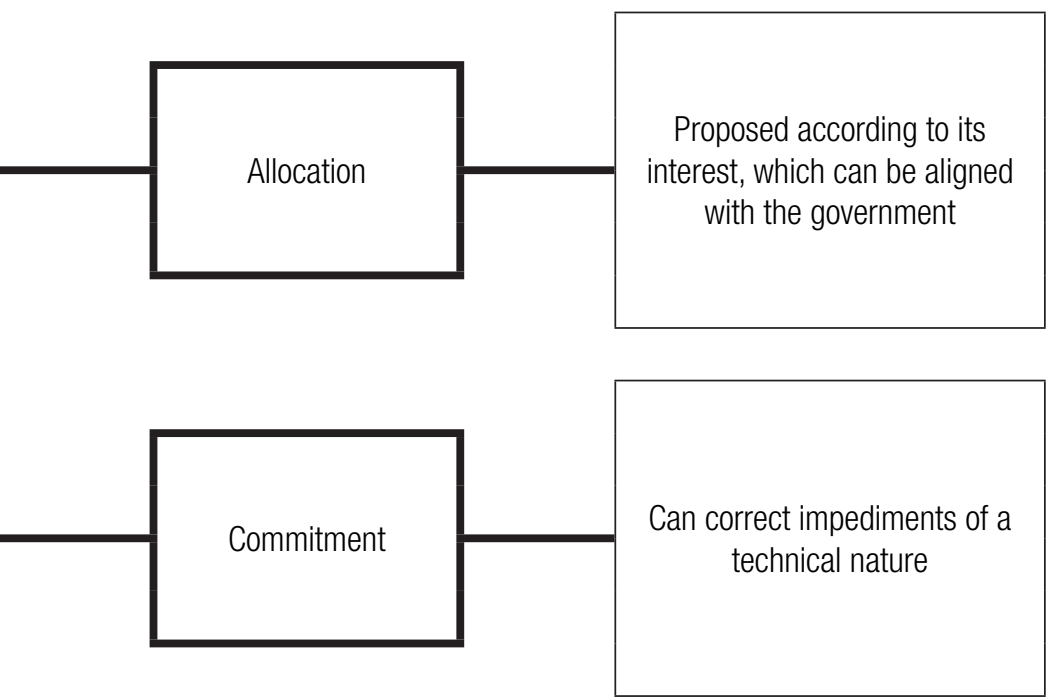

Subject to the executive's discretion in the spending schedule

Source: Elaborated by the authors based on Capellini (2018). 
In principle, the guarantee of commitment to individual amendments (except technical impediments) seems to favor congressmen However, given that the settlement remains subject to discretion, what occurs is just a reduction in the "feeling of a lack of equality" on the part of congressmen, without the equality of values guaranteed in the commitment necessarily being reflected by an equality of the settlement of resources in the contingency schedule. In addition, we should note that if amendments are not settled by the end of the year, ${ }^{5}$ these congressmen may lose commitments to individual amendments (which supposedly are guaranteed by $\$ 11$ of CA 86 (2015) referring to the $1.2 \%$ of current net revenues.

To illustrate the phenomenon addressed in this article, Table 1 summarizes the chronology of investment expenses paid ${ }^{6}$ during the studied period. Note that most of the budgetary expenses in the investment account are specifically paid in the month of December, or in other words, during the last month of the year, with most of this sum designated as remainders to be paid (classified as Unprocessed Remainders to be Paid - URP) which will be settled in the following year.

\section{TABLE 1 INVESTMENT EXPENSES PAID BY THE EXECUTIVE BRANCH (IN R\$ MILLION)}

\begin{tabular}{lcccc} 
Year & \multicolumn{2}{c}{ Month of payment } & Year Total & $\begin{array}{c}\text { Percentage paid in } \\
\text { December }\end{array}$ \\
\hline 2008 & January to November & December & $35 \%$ \\
2009 & 5,848 & 3,094 & 8,941 & $31 \%$ \\
2010 & 9,568 & 4,391 & 13,959 & $25 \%$ \\
2011 & 16,053 & 5,460 & 21,512 & $33 \%$ \\
2012 & 11,162 & 5,495 & 16,657 & $23 \%$ \\
2013 & 16,623 & 4,927 & 21,550 & $25 \%$ \\
2014 & 12,742 & 4,185 & 16,927 & $18 \%$ \\
2015 & 15,566 & 3,494 & 19,060 & $20 \%$ \\
2016 & 7,703 & 1,937 & 9,640 & $52 \%$ \\
2017 & 8,043 & 8,783 & 16,826 & $39 \%$ \\
\hline
\end{tabular}

Source: Elaborated by the Authors based on data from the National Treasury.

\footnotetext{
${ }^{5}$ They would be treated as unprocessed remainders to be paid (considering that the supplier/creditor has fulfilled its performance

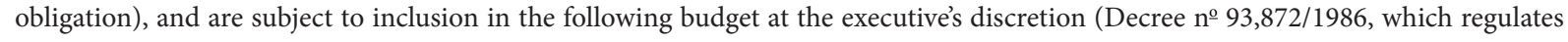
Article 37 of Law no 4,320/1964).

${ }^{6}$ The term "paid" refers to the last stage of the execution of public expenses (commitment, settlement, and payment). Therefore, a "paid" expense means an "executed" expense.
} 
Within this context, it should be noted that a relevant institutional landmark in the management of the treasury's resources was Decree no 93,872/1986, linked to Law no 4,320/1964, which applies in its legal framework the instrument Remainders to be Paid with the intention of making budgetary execution flexible and defines in Article 68, $\$ 1$, , that "the entries envisioned above as unprocessed remainders to be paid are conditioned on the indication of the approver of the expense." This guarantees relative discretion for the approver of expenses in determining the URPs at the end of the fiscal year, except for commitments for daily expenses, cost assistance and the injection of funds.

In this manner, an initial premise of this study is that the executive branch observes the voting decisions of congressmen, mainly regarding agendas presented by the government to congress, and only reward those who are willing to support the executive program with the execution of its amended payments in the budget. The executive can also favor its supporters with a greater distribution of these resources to the detriment of other members of the legislature.

\section{PREVIOUS STUDIES OF THE FORMATION AND MANAGEMENT OF COALITION}

In his pioneering study entitled The Theory of Political Coalitions, Riker (1962) theorizes that the formation of coalition governments should not be concerned with a large number of participants, but the minimum quantity sufficient for control, which guarantees victory for the head of government in congressional decisions. Riker (1962) termed this the "minimum winning coalition". In Brazil, the pioneering work on this subject was Abranches (1988), who invented the term "coalition presidentialism" to refer to the way in which the executive interacts with the legislature.

An analysis of scientific production regarding coalition formation suggests that the political bargain between the executive and the legislature approach to the execution of the Brazilian budget is still incipient. This signifies dependence on the coalition to achieve governability in presidential and multiparty regimes, as measured in the "Index of Coalition Necessity", which determines how much the president depends on coalitions in order to govern (Ames, 1995; Chaisty et al., 2014; Raile, Pereira \& Power, 2011).

The executive branch influences the way in which congressmen vote by strategically selecting which amendments to execute. Pereira and Mueller (2002), in analyzing 325 nominal votes between 1995 and 1998, found evidence which corroborates this affirmation, as did Ravanelli, Costa, and Bonacim (2012), who evaluated the behavior of federal representatives during 2009 and characterized a political bargaining relationship when they found the existence of a positive relationship between votes favorable to the government and approved amendments. Within the national context, Bertholini and Pereira (2017) discussed the formation of coalitions in the administrations of Fernando Henrique Cardoso (FHC), Lula and Dilma and demonstrated the government's coalition management costs through the total quantity of ministries and secretariats, total spending on amendments and total ministerial spending.

This study seeks to fill in a gap in the literature by presenting new evidence about the political bargaining process between the legislative and executive branches. In addition to providing evidence for a longer and more recent period, the econometric method employed in this analysis makes it possible to correct biases in our selected sample.

The next section will deal with the methods employed to analyze the political bargain phenomenon between the years 2000 and 2017 as well as the explored data. 


\section{METHODOLOGY AND DATABASE}

This study uses a quantitative approach of an objectivist ontological and positivist epistemological nature (Ryan, Scapens, \& Theobald, 2002). In particular, it encompasses the budgetary impacts linked to the phenomenon in the quantitative context (in terms of the involvement in the Budgetary Investment account) and the qualitative context (in terms of the characteristics of congressmen who propose amendments which have greater monetary investment).

The data referring to the approved MYP for the years 2000 to 2017 was obtained from the collaboration of the Federal Budgeting Secretariat (SOF) of the Ministry of Planning, Development and Management, based on two large budget data systems: the Integrated System of Planning and Budgeting (Siop) and the Integrated System of Financial Administration (Siafi). This data was obtained from the Citizen's Information Service (SIC). We also had support from the Brazilian Center of Analysis and Planning (Cebrap) to obtain ministerial information, and the House of Representatives Center of Documentation and Information to obtain data relative to the characteristics of the congressmen. ${ }^{7}$

It is important to emphasize that, for this study, just a part of the available observations referring to congressional amendments were used. Since collective amendments are formed by two or more congressmen, we observed a recurring problem with the database furnished by the House of Representatives. In the variables referring to the values of the amendments (initial allotment, value committed, settled and paid) for collective amendments just the total value appears, without separating the corresponding values for each congressman that composed it. The same occurs when we separate amendments according to their programmatic function (amendment identification), which classifies them according to 17 digits, but with no digit identifier of the amendment author. In particular, until 2015, the available information refers to the execution of the total budget for the programmatic function and there is no data for just the execution of the amendment.

Even if an amendment is individual, it can belong to the same programmatic function of various congressmen, without differentiating between the value information for each of them. Since this is recurrent in the database used in this study, we selected just the information for individual amendments which were unique for a given programmatic function. In this study, this type of amendment is denominated a "singular amendment". In counterpart, there are "plural amendments", which are collective amendments which do not have the same programmatic function.

To perform this study, we used two databases for the years 2000 to 2017. The first contains data relative to amendments presented by congressmen, and the second contains characteristics of the amendment authors and their voting behavior on executive bills, as well as the situation of their amendments annexed to the MYP.

In order to verify the relationship between congressional votes on executive bills and the budgetary execution of congressional amendments, it was necessary to take into account the statistical problem with analyses of this type: sample selection bias caused in this case by the exclusive use of data on singular congressional amendments (as mentioned above). Specifically, if the presentation of individual or collective amendments were totally random, the estimation of

\footnotetext{
${ }^{7}$ It should be emphasized that the performed empirical tests do not contemplate party changes by congressmen because this phenomenon is outside the scope of this work.
} 
the simple regression involving just individual amendment data would be consistent rather than biased and therefore would be representative of the population. However, the presentation of individual or collective amendments is not a random phenomenon, but rather an option selected by the congressmen themselves.

It is possible, for example, for some congressmen to propose just amendments together with other congressmen from their faction or at certain times a given congressmen may opt to propose an amendment exclusively for his or her home electoral base. In this sense, estimates involving just data for individual amendments would be subject to sample selection bias, making the results biased and inconsistent and therefore not representative of the population. Thus, we needed to use a method that would deal with this phenomenon.

Heckman (1979) proposes a two-stage estimation procedure to correct this bias. The first stage involves the estimation of an auxiliary regression through which we can calculate the probability of an occurrence of the event of interest which in the proposed study is the probability that a congressman presents an individual amendment (relative to the probability of a congressman presenting a collective amendment). In this way, in a first stage, a probit ${ }^{8}$ type regression is estimated in which the dependent variable assumes a value of " 1 ", if the congressman presents an individual amendment, and " 0 " if the congressman presents a collective amendment. This estimate may be represented by Equation 1:

$$
\operatorname{Prob}(D=1 \mid Z)=Z \cdot \gamma
$$

in which is a binary variable which assumes a value of 1 , if the amendment is individual, and 0 if it is collective. $Z$ represents the matrix of explanatory variables; and $\gamma$ the vector of coefficients of Equation 1 .

Based on this, we perform the second stage which involves estimating the main equation of this study. The dependent variable measures the value of the individual amendment and the selection bias is corrected by incorporating the inverse of Mills's ratio as one of the explanatory variables, which, in turn, is the probability function calculated in the first stage. Equation 2 represents the main (second stage) equation of the study:

$$
E[Y \mid X, D=1]=X \cdot \beta+\lambda \cdot(Z \cdot \gamma)
$$

in which represents the value of individual amendments; , the matrix of explanatory variables of the main equation; $\beta$, the vector of parameters associated with explanatory variables; and , the parameter associated with the inverse of Mills's ratio. Thus, if parameter $\lambda$ is statistically significant, there is evidence of a sample selection bias. In turn, if $\lambda$ is statistically null, there is no bias, and Equation 1 can be estimated in the unbiased and consistent form without needing to include the inverse of Mills's ratio as an explanatory variable.

First, we designated a database containing congressional amendments proposed between 2000 and 2017 for the first stage, as well as their characteristics. Of all of the available amendments, we analyzed just those amendments which are considered singular. We considered 79,923 singular amendments out of a total of 169,235 amendments (singular or plural) proposed by congressmen.

\footnotetext{
${ }^{8}$ Thus, it is assumed that the estimation error term follows a standard normal distribution.
} 
Given the absence of references which analyze the motives which lead congressmen to present individual amendments ( $v i s-\grave{a}-v i s$ collective amendments), the explanatory variables of the first stage of Heckman's approach (1979) were defined based on the characteristics of the explored sample. In the first place, it should be noted that amendments with a specific destination (municipality) are predominantly singular, while plural amendments are characterized by a lack of a precise destination for the financial resources specified in their presentations. In the second place, most of the amendments are linked to the budgetary functions of urbanism, health and leisure. In addition to this, we sought to take into account the possibility of political alignment with governmental ministers influencing the decision of congressmen to present individual amendments. In this way, Box 1 presents the variables used in the first stage.

\section{BOX 1 FIRST STAGE VARIABLES 9}

\begin{tabular}{|c|c|}
\hline Variable & Definition \\
\hline $\begin{array}{l}\text { Type of amendment - } \\
\text { dependent variable }\end{array}$ & 1 , if the amendment is singular; 0 , if not \\
\hline Ministry - party - coalition & $\begin{array}{l}\text { 1, if the congressman is affiliated with a coalition party and dedicated his or her } \\
\text { amendment to some ministry controlled by one of the coalition parties (even if } \\
\text { different from the congressman); } 0 \text {, if not }\end{array}$ \\
\hline Amendment - municipality & 1 , if the amendment is specifically dedicated to a municipality; 0 , if not \\
\hline Amendment - urbanism & 1 , if the amendment is characterized as an urbanism expense; 0 if not \\
\hline Amendment - leisure & 1 , if the amendment is characterized as a leisure expense; 0 , if not \\
\hline Amendment - health & 1 , if the amendment is characterized as a health expense; 0 , if not \\
\hline Dummies for State & Dummies for each state in the sample \\
\hline Dummies for Year & Dummies for each year in the sample \\
\hline
\end{tabular}

Source: Elaborated by the Authors.

Box 2, in turn, is defined based on the existing literature as well as the sample characteristics, and presents the variables used in the main (second stage) model.

\footnotetext{
${ }^{9}$ The year dummies have the objective of controlling estimates for the specific effects of each sample year which are common to all of the observations, such as the occurrence of macroeconomic shocks or the fact that they are election years, for example.
} 


\begin{tabular}{|c|c|c|}
\hline Variable & Definition & Previous studies \\
\hline $\begin{array}{l}\text { Settlement value (in natural } \\
\text { logarithms) logaritmo natural) - } \\
\text { variável dependente }\end{array}$ & $\begin{array}{l}\text { Settlement value of all amendments of a given } \\
\text { congressman (in natural logarithms) }\end{array}$ & \\
\hline $\begin{array}{l}\text { Proportion of favorable votes in } \\
\text { the past }\end{array}$ & $\begin{array}{l}\text { Proportion of favorable votes by congressman i for } \\
\text { executive bills in year } \mathrm{t}-1\end{array}$ & Alston and Muller (2001) \\
\hline Proportion settled & $\begin{array}{l}\text { Proportion of the total settlement value of all the } \\
\text { amendments proposed by congressman i in year } t\end{array}$ & - \\
\hline $\begin{array}{l}\text { President/Vice President - } \\
\text { commission }\end{array}$ & $\begin{array}{l}\text { 1, if congressman } \mathrm{i} \text { is the president or vice president of a } \\
\text { commission in year } \mathrm{t} \text {; } 0 \text {, if not }\end{array}$ & - \\
\hline Leftist party & $\begin{array}{l}\text { 1, if the ideology of the party of congressman } \mathrm{i} \text { is classified } \\
\qquad \text { as leftist; } 0 \text {, if not }\end{array}$ & $\begin{array}{c}\text { Pereira and Mueller } \\
\text { (2002); Rodrigues (2002); } \\
\text { Tarouco and Madeira } \\
\text { (2013); Maciel, Alarcon e } \\
\text { Gimenes (2018) }\end{array}$ \\
\hline Party of the government coalition & $\begin{array}{l}\text { 1, if the party of congressman i belongs to the government } \\
\text { coalition; } 0 \text {, if not }\end{array}$ & - \\
\hline $\begin{array}{l}\text { Proportion of amendments - } \\
\text { coalition }\end{array}$ & $\begin{array}{l}\text { Proportion of amendments that a congressman affiliated } \\
\text { with a coalition party dedicated to a ministry which is also } \\
\text { controlled by the coalition (even if it is a different party) }\end{array}$ & Luz (2017) \\
\hline $\begin{array}{l}\text { Proportion of amendments - } \\
\text { municipalities }\end{array}$ & $\begin{array}{l}\text { Proportion of amendments dedicated specifically to } \\
\text { municipalities }\end{array}$ & - \\
\hline Inverse of Mills's Ratio & Inverse of Mills's Ratio (estimated for the first stage) & - \\
\hline Dummies/year & Dummies for each year of the sample & - \\
\hline
\end{tabular}

Source: Elaborated by the Authors.

In accordance with the model proposed by Heckman (1979), because the first stage in this study used a different database from the second stage, we sought to adapt the model in question. Initially, we constructed two databases: the first, used in the first stage, in which each observation refers to an individual amendment, and the second, used in the second stage, in which each observation refers to a congressman and contains variables such as the number of votes favorable to the executive and party ideology, among other variables.

\footnotetext{
${ }^{10}$ We wish to clarify that the settlement values were transformed into Napierian logarithms to diminish the chance of the estimates generating heteroscedastic errors, which would violate one of the classic assumptions of the linear regression method (that the errors are homoscedastic). The estimates of the second stage also included dummies for the year as explained in the previous footnote.
} 
Based on the first database, we estimated Equation 1 in such a way that for each observation (amendment) we calculated the probability that it was individual. Next, we calculated the average probability per congressman and, based on this average, we finally calculated the inverse of Mills's ratio. Subsequently using the second database, we estimated the main model (Equation 2) using estimators for OLS, fixed effects and random effects. In particular, for the selection of the most appropriate estimation method among the last two mentioned, we used the Hausman test, which evaluates the consistency of the two estimators.

\section{RESULTS}

This section presents the results of the estimates, described in the previous topic of this article, according to the methodology proposed by Heckman (1979). Table 2 displays the results of the first stage separated by legislature.

\section{TABLE 2 FIRST STAGE RESULTS}

\begin{tabular}{|c|c|c|c|c|c|c|c|c|c|c|}
\hline \multirow{3}{*}{$\begin{array}{l}\text { Explanatory } \\
\text { variable }\end{array}$} & \multicolumn{10}{|c|}{ Legislatures } \\
\hline & \multicolumn{2}{|c|}{$51^{\text {st }}$} & \multicolumn{2}{|c|}{$52^{\text {nd }}$} & \multicolumn{2}{|c|}{$53^{\text {rd }}$} & \multicolumn{2}{|c|}{$54^{\text {th }}$} & \multicolumn{2}{|c|}{$55^{\text {th }}$} \\
\hline & Coef. & $p$-value & Coef. & $p$-value & Coef. & $\mathrm{p}$-value & Coef. & $\mathrm{p}$-value & Coef. & $p$-value \\
\hline $\begin{array}{l}\text { Ministry - party } \\
\text {-coalition }\end{array}$ & 0.212 & 0.000 & 0.256 & 0.000 & 0.212 & 0.000 & 0.461 & 0.000 & 0.360 & 0.000 \\
\hline $\begin{array}{l}\text { Amendment - } \\
\text { municipality }\end{array}$ & 1.863 & 0.000 & 1.823 & 0.000 & 1.683 & 0.000 & 1.535 & 0.000 & 1.791 & 0.000 \\
\hline $\begin{array}{l}\text { Amendment - } \\
\text { urbanism }\end{array}$ & -0.404 & 0.000 & -0.669 & 0.000 & -0.594 & 0.000 & -0.314 & 0.000 & -0.387 & 0.000 \\
\hline $\begin{array}{l}\text { Amendment - } \\
\text { leisure }\end{array}$ & 0.349 & 0.000 & 0.083 & 0.016 & -0.164 & 0.000 & -0.131 & 0.000 & -0.239 & 0.000 \\
\hline $\begin{array}{l}\text { Amendment - } \\
\text { health }\end{array}$ & -0.116 & 0.000 & -0.464 & 0.000 & -0.380 & 0.000 & -0.957 & 0.000 & -0.586 & 0.000 \\
\hline Observations & \multicolumn{2}{|c|}{26,925} & \multicolumn{2}{|c|}{33,833} & \multicolumn{2}{|c|}{38,310} & \multicolumn{2}{|c|}{42,754} & \multicolumn{2}{|c|}{27,413} \\
\hline Pseudo- $R^{2}$ & \multicolumn{2}{|c|}{0.328} & \multicolumn{2}{|c|}{0.361} & \multicolumn{2}{|c|}{0.279} & \multicolumn{2}{|c|}{0.274} & \multicolumn{2}{|c|}{0.302} \\
\hline
\end{tabular}

Notes: The estimates were obtained using the probit method. The dependent variable is a binary variable which assumes the value 1 if the amendment is singular and 0 if it is collective. The model was controlled for dummies representing the state.

Source: Elaborated by the Authors.

According to the results presented in Table 2, we may observe that the parameter associated with the explanatory variable Ministry - party - coalition is positive and statistically significant in all of the estimates. This result indicates the fact that an amendment presented by a congressman who belongs to the government coalition is dedicated to a ministry which is also controlled by a party of the government coalition increases the probability that this amendment will be singular (as opposed to collective). 
The parameters that refer to the explanatory variable Amendment - municipality are also positive and statistically significant in all of the estimates. This result suggests that the dedication of an amendment to a given municipality increases the chances that it is individual. This may suggest that the majority of singular amendments are applied to a given municipality already defined in its presentation. This is an expected political effect, because congressmen tend to dedicate amendments to their home electoral base, and these amendments are known in the literature as pork barrel amendments (Fukui \& Fukai, 1996; Golden \& Picci, 2008; Pereira \& Orellana, 2009; Wilson, 1986).

In terms of the coefficients that refer to the programmatic finality of a congressional amendment, it is possible to observe that all of the coefficients associated with the explanatory variables Amendment - urbanism and Amendment - health are negative and statistically significant. This fact suggests that amendments dedicated to these areas are less associated with individual amendments. In turn, the coefficients associated with the explanatory variable Amendment - leisure are positive in the $51^{\text {st }}$ and $52^{\text {nd }}$ legislatures, which indicates a greater probability that it is individual if it is dedicated to this function, but negative in the other legislatures, signaling a lower probability of being individual.

The parameters presented in Table 2 serve to calculate the inverse of Mills's ratio, which is inserted as the explanatory variable in the second stage, whose results are presented in Table 3. Given that the Hausman test ${ }^{11}$ was indicated as the most appropriate method for random effects, the following analyses were made based on the results obtained based on this estimation method. Table 3 presents the parameters associated with each explanatory variable,${ }^{12}$ their respective $\mathrm{p}$-values and the coefficient of determination $\left(\mathrm{R}^{2}\right)$.

\section{TABLE $3 \quad$ RESULTS OF THE MAIN MODEL (SECOND STAGE)}

\begin{tabular}{lcc}
\hline Explanatory variable & Coef. & p-value \\
\hline Proportion of favorable votes in the past & 0.268 & 0.088 \\
Proportion settled & 2.599 & 0.000 \\
President/Vice President - commission & -0.002 & 0.966 \\
Leftist party & 0.203 & 0.000 \\
Government coalition party & -0.160 & 0.000 \\
Proportion - amendments - ministries - coalition & 0.036 & 0.702 \\
Proportion - amendments - municipalities & 0.538 & 0.000
\end{tabular}

\footnotetext{
${ }^{11}$ The robust Hausman test, with a confidence level of 5\%, generated a p-value of 0.5081 , indicating it as the most appropriate (consistent and efficient) to estimate random effects.

${ }^{12}$ The $\mathrm{F}$ test presented Prob $>\mathrm{F}=0.000$, which classifies the model as statistically significant. The Breush-Pagan test presented Prob $>$ chi2 $=0.000$, thus rejecting the null hypothesis of homoscedasticity. The Wooldridge presented Prob $>\mathrm{F}=0.9203$, thus accepting the null hypothesis of an absence of autocorrelated residuals. The Chow test presented Prob $>\mathrm{F}=0.000$, indicating the panel data method as the preferred method for estimating by OLS. The Variance Inflation Factor did not detect the presence of multicollinearity in any of the model's explanatory variables.
} 


\begin{tabular}{lcc} 
Explanatory variable & Coef. & p-value \\
\hline Inverse of Mills's ratio & -0.538 & 0.000 \\
Constant & 12.130 & 0.000 \\
Observations & & 2,718 \\
$\mathrm{R}^{2}$ & & 0.428 \\
\hline
\end{tabular}

Notes: The dependent variable is the settled value of the amendments as a natural logarithm; the explanatory variable Proportion of favorable votes in the past refers to the proportion of the congressman's votes which were favorable to executive branch bills in the previous year. The results were obtained by the random effects model. The model was controlled using dummies for each year with the objective of controlling the estimates for specific effects of each year of the sample.

Source: Elaborated by the Authors.

According to the results of the estimates, the main explanatory variable of this study, the congressman's proportion of favorable votes on executive bills (for the year before the execution of the amendments) has a positive and statistically significant relationship at $10 \%$ with the executed value of the congressional amendments. This result suggests that, the greater the support that a congressman gives the executive branch in congressional votes (in a given year), the greater will be the investment in the congressman's amendments (in the following year). In this way, this characterizes the phenomenon of political bargaining in the execution of the federal budget. As theorized in this article, there are results that corroborate the hypothesis that the executive uses discretion in the execution of amendments to manage its coalition. According to the obtained results, an increase in 10 percentage points in congressional votes favorable to executive bills (in a given year) elevates on average the settled value of a congressman's amendments by almost three percentage points in the following year.

In respect to the variable which defines the proportion of the values of settled amendments in relation to what was presented by their congressional authors (Proportion settled), inserted in the model as a control variable, it should be noted that its coefficient is positive and statistically significant at a $5 \%$ level. This result suggests that the settled value of proposed amendments by a given congressman is intimately linked to the proportion settled of all proposed amendments in such a way that the larger this proportion is, the greater the total value executed will be.

In relation to the exercise of leadership in congress and its influence on the execution of amendments, the coefficient associated with the variable which defines whether the congressman was a president or vice president of a commission during a given year (President/Vice President - commission) did not present statistical significance. This suggests, therefore, that the fact that a congressman has high posts in congressional commissions does not have an effect on the executed value of the amendments that he or she authors.

In analyzing ideology, the results suggest that the fact that the congressman is from a Leftist Party increased the value executed in amendments by approximately $20 \%$. Note that the coefficient associated with this explanatory variable is positive and statistically significant at a $5 \%$ level.

In terms of the explanatory variable Government coalition party, the coefficient was negative and statistically significant. This fact suggests that congressmen belonging to the government party coalition have a lower executed value in their amendments compared to congressmen associated with parties that are not part of the coalition. Even though this result appears to be paradoxical, a possible interpretation of this is that a coalition congressman who is already aligned with the government has other mechanisms to make his or her public policies viable besides amendments, and can propose 
policies that already appear in the budget, before the proposal of amendments. Thus, there will be no opposition from these congressmen to having their amendments executed in a smaller proportion than those of opposition congressmen.

Analyzing the effect of the explanatory variable Proportion - amendments - ministries - coalition, we can observe that its coefficient is positive, but that it is not statistically significant. Thus, the results suggest that there is no relationship between the settled value of an amendment and the fact that the congressman belongs to a coalition party and dedicates amendments to a ministry whose minister is also from a coalition party.

The results of the estimates also suggest that the larger the proportion is of singular amendments dedicated to predefined municipalities, the greater the value of its settlement value, because the coefficient associated with the Proportion - amendments - municipalities is positive and statistically significant.

Inserted into the estimates with the objective of making them unbiased and consistent, the coefficient associated with the inverse of Mills's ratio is statistically significant at a level of $1 \%$. This result suggests the existence of a sample selection bias, or in other words, the decisions made by congressmen to present individual amendments (relative to presenting collective amendments) is not random. As mentioned, the control for this sample selection bias is one of the main contributions of this study, given that the existing literature ignores this effect.

For comparative purposes, the results presented in Table 4 refer to an alternative model in which the dependent variable is substituted by the number of settled amendments, and the sample selection bias is abandoned. Among other things, note that the non-inclusion of the inverse of Mills's ratio makes the coefficient of the model's main explanatory variable of the congressman's favorable votes for executive bills no longer statistically significant. Thus, studies which ignore the presence of the sample selection bias would arrive at mistaken conclusions about the studied phenomenon.

\section{TABLE $4 \quad$ RESULTS OF THE MAIN MODEL WITHOUT CORRECTING FOR SAMPLE SELECTION BIAS}

$\begin{array}{lcc}\text { Explanatory variable } & \text { Coef. } & \text { p-value } \\ \text { Proportion of favorable votes in the past } & 0.157 & 0.819 \\ \text { Proportion settled } & 1.567 & 0.000 \\ \text { President/Vice President - commission } & 0.182 & 0.392 \\ \text { Leftist party } & 1.045 & 0.000 \\ \text { Government coalition party } & -0.011 & 0.950 \\ \text { Proportion - amendments - ministries - coalition } & 0.465 & 0.249 \\ \text { Proportion - amendments - municipalities } & 12.304 & 0.000 \\ \text { Constant } & 0.952 & 0.073 \\ \text { Observations } & & 2.948 \\ \text { R }^{2} & & 0.499\end{array}$

Notes: The dependent variable is the quantity of settled amendments; the explanatory variable Proportion offavorable votes in the past refers to the proportion of favorable votes that the congressman cast for executive bills in the previous year. Source: Elaborated by the Authors. 
The results suggest that the level of support of the representatives of the government coalition is related to the increase in settlements of amendments, which corroborates the hypothesis of the existence of political bargains between the executive and legislative branches. For a period still without the possible effects of the practices of the imposed budget (Constitutional Amendment $\mathrm{n}^{\mathrm{o}} 86$ and Constitutional Amendment $n^{\circ}$ 100), the results suggest that bargaining practices sustained by pork barrel legislation were replicated as a governability mechanism by coalition governments.

\section{FINAL CONSIDERATIONS}

This study's central objective has been to analyze the relationship between the executive and legislative branches in the Brazilian budgeting process. In particular, this study has been concerned with finding evidence of the phenomenon of political bargaining between these branches, as well as characterizing the congressmen who opt to participate in this relationship.

The theoretical framework, based on Coalition Formation Theory, not only sustained the hypotheses raised here, but also elucidates this phenomenon and makes it possible to approach it from a perspective of the budgetary controllership and planning applied to public governance. Based on econometric estimates which consider the presence of a sample selection bias, the obtained results led to a rejection of the null hypothesis raised in this study, that congressmen who support the executive with favorable votes in congress do not benefit more from the execution of their amendments than other congressmen. Thus, we have found evidence that there exists a political bargaining relationship between the executive and legislative branches in the execution of public budgeting.

The obtained results suggest that congressmen with greater investment in the execution of their singular amendments during the period of 2000 to 2017 were those which, in addition to having supported the executive with favorable votes on the bills sent to congress, were outside of the government coalition and obtained a significant portion of settled amendments. In addition, another important result has to do with the fact that the congressmen who most benefitted from the execution of their amendments were those who proposed singular amendments dedicated to specific municipalities. In fact, a good portion of the amendments which are exclusive to a single congressman (individual amendments) have quite a common characteristic: they are dedicated explicitly to municipalities which probably were essential to the candidacies of the respective proposers of these amendments. This corroborates the literature about pork barrel projects.

In a broader manner, the results of this study indicate that the executive branch has an important chance to differentiate the allocations for the execution of congressional amendments in accordance with the characteristics of the congressmen which draw more of their attention, such as ideology, an explicit position of support or opposition to the government and the principal one: their behavior in votes on the implementation of the government's bills and the formation of its coalition. Finally, in respect to prospects for future research agendas, the authors suggest analyzing occasional changes in the bargaining process between the executive and legislative branches in the new context of the imposed amendments proposed by CA no 86 (2015) and CA no 100 (2019). This approach could present results that will enable the characterization of the relationship between the branches in light of these important institutional changes. 


\section{REFERENCES}

Abranches, S. (1988). Presidencialismo de coalizão: o dilema institucional brasileiro. Dados, 31(1), 5-38.

Alston, L. J., \& Mueller, B. (2001). Pork for policy: executive and legislative exchange in Brazil. Journal of Law, Economics, and Organization, 22(1), 87-114.

Ames, B. (1995). Electoral rules, constituency pressures, and pork barrel: bases of voting in the Brazilian Congress. The Journal of Politics, 57(2), 324-343

Bertholini, F., \& Pereira, C. (2017). Pagando o preço de governar: custos de gerência de coalizão no presidencialismo brasileiro. Revista de Administração Pública, 51(4), 528-550.

Capellini, G. A. (2018). Execução de emendas parlamentares e orçamento impositivo brasileiro (Doctoral Dissertation). Universidade de São Paulo, Ribeirão Preto, SP.

Chaisty, P., Cheeseman, N., \& Power, T. (2014). Rethinking the 'presidentialism debate': conceptualizing coalitional politics in cross-regional perspective. Democratization, 21(1), 72-94.

Cheibub, J. A., Przeworski, A., \& Saiegh, S. M. (2004). Government coalitions and legislative success under presidentialism and parliamentarism. British Journal of Political Science, 34(4), 565-587.

Constituição da República Federativa do Brasil de 1988. (1988). Constituição promulgada em 5 de outubro de 1988, Brasília, DF.

Decreto $n^{\circ}$ 93.872, de 23 de dezembro de 1986. (1986). Dispõe sobre a unificação dos recursos de caixa do Tesouro Nacional, atualiza e consolida a legislação pertinente e dá outras providências. Retrieved from http://www.planalto.gov.br/ccivil_03/decreto/ d93872.htm

Emenda constitucional $n^{\circ} 86$ de 17 de março de 2015. (2015). Altera os arts. 165, 166 e 198 da Constituição Federal, para tornar obrigatória a execução da programação orçamentária que especifica. Retrieved from http://www.planalto.gov. br/cci-vil_03/constituicao/Emendas/Emc/emc86. htm

Emenda constitucional $n^{\circ} 100$ de 26 de junho de 2019. (2019). Altera os arts. 165 e 166 da Constituição Federal para tornar obrigatória a execução da programação orçamentária proveniente de emendas de bancada de parlamentares de Estado ou do Distrito Federal. Retrieved from http://www. planalto.gov.br/ccivil_03/constitui-cao/emendas/ emc/emc100.htm

Figueiredo, A. C., \& Limongi, F. D. M. P. (2006). Poder de agenda na democracia brasileira: desempenho do governo no presidencialismo pluripartidário. Reforma política: lições da história recente. Rio de Janeiro, RJ: FGV.

Fukui, H., \& Fukai, S. N. (1996). Pork barrel politics, networks, and local economic development in contemporary Japan. Asian Survey, 36(3), 268-286.

Giacomoni, J. (2008). Orçamento público. São Paulo, SP: Atlas.

Golden, M. A., \& Picci, L. (2008). Pork-barrel politics in postwar Italy, 1953-94. American Journal of Political Science, 52(2), 268-289.

Gontijo, V. (2010). Orçamento impositivo, contingenciamento e transparência. Cadernos Aslegis, 39, 61-72.

Greggianin, E., \& Silva, J. R. P. (2015). O regime do orçamento impositivo das emendas individuais disposições da Emenda Constitucional no ${ }^{\circ}$ 86, de 2015, e da LDO 2015 (Estudo Técnico Conjunto ${ }^{\circ}$ 1, de 2015). Brasília, DF: Consultoria de Orçamento e Fiscalização Financeira da Câmara dos Deputados e Consultoria de Orçamentos, Fiscalização e Controle do Senado Federal.

Heckman, J. J. (1979). Sample selection bias as a specification error. Econometrica, 47(1), 153-161

Kanayama, R. L. (2009). A ineficiência do orçamento público impositivo. Revista de Direito Público da Economia, 7(28), 127-144.

Kang, W. (2018). The past is long-lasting: Park Chung Hee nostalgia and voter choice in the 2012 Korean presidential election. Journal of Asian and African Studies, 53(2), 233-249.

Lei $n^{\circ}$ 4.320, de 17 de março de 1964. (1964). Estatui Normas Gerais de Direito Financeiro para elaboração e controle dos orçamentos e balanços da União, dos Estados, dos Municípios e do Distrito Federal. Retrieved from http://www.planalto.gov.br/ ccivil_03/leis/14320.htm

Lima, E. M., \& Viana, P. R. N. (2016). As relações entre o Executivo e o Legislativo na elaboração do 
orçamento brasileiro: considerações sobre a emenda constitucional 86/2015. Revista de Direito Tributário e Financeiro, 2(2), 199-220.

Limongi, F., \& Figueiredo, A. (1998). Bases institucionais do presidencialismo de coalizão. Lua Nova: Revista de Cultura e Política, 44, 81-106.

Luz, J. H. (2017). Politica ministerial: as emendas individuais orçamentárias no presidencialismo de coalizão brasileiro (Doctoral Dissertation). Universidade de São Paulo, São Paulo, SP.

Maciel, A. P. B., Alarcon, A. O., \& Gimenes, E. R. (2018). Partidos políticos e espectro ideológico: parlamentares, especialistas, esquerda e direita no Brasil. Revista Eletrônica de Ciência Política, 8(3), 72-88.

Martins, U. L. (2016). Orçamento impositivo brasileiro: reflexão sobre os avanços e as limitações decorrentes da Emenda Constitucional n. 86/2015. Revista de Direito Tributário e Financeiro, 2(2), $382-398$

Pereira, C. (2000). What are the conditions for the presidential success in the Legislative arena? The Brazilian electoral connection (Doctoral Dissertation). New School for Social Research, Nova York, NY.

Pereira, C., \& Mueller, B. (2002). Comportamento estratégico em presidencialismo de coalizão: as relações entre Executivo e Legislativo na elaboração do orçamento brasileiro. Dados, 45(2), 265-301.

Pereira, C., \& Orellana, S. (2009). Hybrid political institutions and governability: the budgetary process in Brazil. Journal of Politics in Latin America, 1(3), 57-79.

Raile, E. D., Pereira, C., \& Power, T. J. (2011). The executive toolbox: Building legislative support in a multiparty presidential regime. Political Research Quarterly, 64(2), 323-334.

Ravanelli, R., Costa, D. R. M., \& Bonacim, C. A. G. (2012). Indicativos da existência de barganha no processo orçamentário brasileiro. In Anais do Congresso USP de Controladoria e Contabilidade, Ribeirão Preto, SP.

Riker, W. (1962). The theory of political coalitions. New Haven, CO: Yale University Press.

Rodrigues, L. M. (2002). Partidos, ideologia e composição social: um estudo das bancadas partidárias na Câmara dos Deputados. São Paulo, SP: Edusp.

Ryan, B. \& Scapens, R. W., \& Theobald, M. (2002). Research method and methodology in Finance and Accounting. Londres, UK: Thomson.

Santos, F. (2002). Partidos e comissões no presidencialismo de coalizão. Dados, 45(2), 237-264.

Scartascini, C.; Crain, W. M. (2001). The size and composition of government spending in multi-party systems. In Proceedings of Public Choice Society Conference, San Antonio, Texas.

Tarouco, G. S.; Madeira, R. M. (2013). Partidos, programas e o debate sobre esquerda e direita no Brasil. Revista de Sociologia e Política, 21(45), 149165.

Weingast, B. R., Shepsle, K. A., \& Johnsen, C. (1981). The political economy of benefits and costs: A neoclassical approach to distributive politics. Journal of Political Economy, 89(4), 642-664.

Wilson, R. K. (1986). An empirical test of preferences for the political pork barrel: District level appropriations for river and harbor legislation, 1889-1913. American Journal of Plitic ${ }^{1}$ al Science, 30(4), 729-754 


\section{Luis Henrique Teixeira Graton}

https://orcid.org/0000-0003-3076-5197

Master's Degree in Controllership and Accounting from the University of São Paulo; Professor at the Faculty of Philosophy, Sciences and Letters in Ituverava. E-mail: lhtgraton@gmail.com

\section{Carlos Alberto Grespan Bonacim}

https://orcid.org/0000-0003-0347-9419

Ph.D. in Controllership and Accounting from University of São Paulo; Professor at FEA-RP/USP.

E-mail: carlosbonacim@usp.br

\section{Sérgio Naruhiko Sakurai}

https://orcid.org/0000-0002-7515-0340

Ph.D. in Economics from University of São Paulo; Professor at FEA-RP/USP. E-mail: sakurai@usp.br 